\title{
PHYTOCHEMICAL, NUTRITIONAL AND ANTIOXIDANT CHARACTERISTICS OF WHITEBEAM (SORBUS ARIA) FRUITS
}

\author{
Nadezhda Tr. Petkova ${ }^{1 凶}$, Manol H. Ognyanov², Radka Z. Vrancheva3, Peter Zhelev \\ ${ }^{1}$ Department of Organic Chemistry and Inorganic Chemistry, University of Food Technologies \\ Maritza Blvd. 26, 4002 Plovdiv, Bulgaria \\ ${ }^{2}$ Institute of Organic Chemistry with Centre of Phytochemistry, Bulgarian Academy of Sciences, Laboratory of Biologically Active \\ Substances \\ Ruski Blvd. 139, 4000 Plovdiv, Bulgaria \\ ${ }^{3}$ Department of Analytical Chemistry and Physical Chemistry, University of Food Technologies \\ Maritza Blvd. 26, 4002 Plovdiv, Bulgaria \\ ${ }^{4}$ Dendrology Department, University of Forestry \\ Kliment Ohridski Blvd. 10, 1756 Sofia, Bulgaria
}

\begin{abstract}
Background. Common whitebeam, Sorbus aria (L.) Crantz is an European and Near-Eastern deciduous tree with small red fruits. However, the edible use of this forest fruit is currently not widespread. Also, its nutritional and antioxidative properties remained undiscovered. In this study, the chemical composition and antioxidant properties of common whitebeam fruit were investigated.

Materials and methods. The fruit were collected from Golo Bardo Mountain in Bulgaria. The phytochemical (carotenoids, phenolic compounds, flavonoids), nutritional (moisture, ash, titrable acidity, lipids, proteins, pectin, carbohydrates) and antioxidant activity were evaluated by four assays (DPPH, ABTS, FRAP, and CUPRAC). Results. Sugar analysis demonstrated that only fructose and glucose were detected in the fruit. Pectin content did not exceed $1.30 \%$. Moreover, the fruit had a low lipid content $(0.80 \%)$. The whitebeam fruit were also characterized as a source of carotenoids $(1.69 \mathrm{mg} / 100 \mathrm{~g}$ fresh weight, fw), phenolic compounds (32.42 $\mathrm{mg}$ $\mathrm{GAE} / 100 \mathrm{~g} \mathrm{fw}$ ), and flavonoids (20.08 mg QE/100 g fw). Among phenolic acids, only 2,4-dihydrohybenzoic, caffeic, $p$-coumaric, and sinapic acid were detected. The antioxidant potential of the fruit was from 168.52 $\mathrm{mM} \mathrm{TE} / 100 \mathrm{~g}$ fw (FRAP) to $244.81 \mathrm{mM}$ TE/100 $\mathrm{g}$ fw (CUPRAC assay).

Conclusion. The current research enriched the available information about the nutritional potential and chemical composition of common whitebeam fruit and their low sugar content. The absence of sucrose, together with its high phenolic content, demonstrated the potential of this fruit for future application in food products and supplements.
\end{abstract}

Keywords: whitebeam, biological activity, nutrients, pectin, phenolic acids, pigments

\section{INTRODUCTION}

Sorbus aria (L.) Crantz, known as common whitebeam, is a member of the genus Sorbus, subfamily Maloideae, Rosaceae family (Olszewska, 2008). It is a slow-growing, small to medium-sized deciduous tree or shrub that can reach $20 \mathrm{~m}$, but usually is up to 5-15 tall and $40 \mathrm{~cm}$ in diameter (Welk et al., 2016). It is characterized by a long lifespan (100-200 years) and starts fruiting from 10-20 years of age. Sorbus 
aria occurs in almost all mountainous and hilly regions of southern and central Europe, from the Iberian Peninsula and southern Italy eastwards to the Balkans and the Carpathian Mountains and northern parts of Africa as well (Olszewska and Michel, 2012; Welk et al., 2016). In Bulgaria, Sorbus aria is a widespread tree mainly found in the mountains (Rila, Pirin, Rhodopes, Vitosha, Lulin, and Stara Planina) between 800 and $1700 \mathrm{~m}$ altitude. It is not found in the eastern and southeastern parts of the country (Michev et al., 1983). The flowering period of common whitebeam is from May to June, and the fruit ripen from September to October (Michev et al., 1983; Welk et al., 2016). They are orange to scarlet globose pomes of $8-15 \mathrm{~mm}$ in diameter with 2 to 4 seeds and many lenticels on the skin. S. aria, together with fruits of several Sorbus species, is used as a food ingredient and also as traditional diuretic, anti-inflammatory, antidiarrhoeal (dried fruit) and vasodilatory agents and for its vitamin content (Michev et al., 1983; Olszewska, 2008). Common whitebeam fruit can be eaten fresh, dried or processed as jams, jellies, marmalade, conserves, syrup, vinegar, brandy, liqueurs, and fruit wine (Michev et al., 1983; Olszewska and Michel, 2012; Šavikin et al., 2017) or added into a bread flour (German name "Mehlbeere = Flour Berry"). In frozen or cooked form, the fruit are edible, but not too tasty (Welk et al., 2016). The astringent taste of the fruit is due to phenolic compounds (Michev et al., 1983). The taste and quality of the fruit strongly depend on its phytochemical composition and therefore a determination of its qualitative and quantitative characteristics becomes of great importance.

The chemical composition and antioxidant activity of the Sorbus aria fruit have not been studied in detail. Some fragmentary data about carotenoids, phenolic acids, and flavonoids have been reported for fruit collected from Serbia and Montenegro (Šavikin et al., 2017). Flavonol aglycones in hydrolyzed extracts from Polish Sorbus aria (L.) Crantz fruit have been reported (Olszewska, 2008). The antioxidant potential of some Sorbus species such as Sorbus aucuparia, Sorbus domestica, Sorbus aria, etc. has been demonstrated (Hukkanen et al., 2006; Olszewska, 2008; Šavikin et al., 2017; Termentzi et al., 2006; Zymone et al., 2008). However, the qualitative and quantitative characteristics of phenolic compounds strongly depend on various genotypic and environmental factors. Information about the detailed chemical composition and antioxidant activity of Sorbus aria from the Balkan Peninsula, especially in Bulgaria, is very limited or lacking. Moreover, nutrients such as carbohydrates, including pectins and sugars, have not been studied. To the best of our knowledge, no detailed study has been carried out on the physicochemical, nutritional characterization, and antioxidant activity of Sorbus aria fruit up to now. Therefore, the purpose of this study was to carry out a detailed analysis of the content of major bioactive substances in these fruit grown in Bulgaria and the evaluation of their antioxidant potential.

\section{MATERIALS AND METHODS}

\section{Materials}

Sorbus aria fruit were harvested from a village called Kralev dol (Pernik, Bulgaria) on Golo Bardo mountain at an altitude of $796 \mathrm{~m}$, latitude $42.56667^{\circ}$, and $23.083333^{\circ}$ longitude during the end of September 2018 in the full ripening stage, when the skin obtained a deep red to wine red colour. The samples were collected by a botanist from the University of Forestry, Sofia, Bulgaria, and characterized by them. The plant material was deposited in the Herbarium of the Institute of Biodiversity and Ecosystem Research at the Bulgarian Academy of Sciences with a voucher specimen number SOM 177019. The fruit were immediately transferred to the laboratory in a plastic bag. The collected raw material was cleaned, washed out, the seeds were removed from the pulp and the fruit mass was stored at $-18^{\circ} \mathrm{C}$ until further analysis.

\section{Chemicals}

All the solvents and reagents were of analytical grade and were purchased from Sigma-Aldrich (St. Louis, MO, USA) and Fillab (Plovdiv, Bulgaria). The reagents were used directly without further pretreatment.

Chemical composition. Moisture content (\%) was determined after drying at $105^{\circ} \mathrm{C}$ until constant weight (AOAC, 2007). Ash content (\%) was determined by igniting the sample in a muffle furnace (MLW, Germany) at $550^{\circ} \mathrm{C}$ for $4 \mathrm{~h}$ (AOAC, 2007). $\mathrm{pH}$ was measured using a pH meter 7110 WTW (Weilheim, Germany). Titratable acidity (TA) was measured potentiometrically by titration with $0.1 \mathrm{M} \mathrm{NaOH}$ to the $\mathrm{pH}$ value 
of 8.1 and the result was expressed as $g$ of malic acid equivalent per $100 \mathrm{~g}$ fresh weight (fw). The crude protein content was estimated using the micro-Kjeldahl method (Bradstreet, 1965). The nitrogen content of the digested sample, expressed as ammonia, was determined by the acetylacetone-formaldehyde colorimetric method using ammonium sulfate as a standard (National Food Safety Standard of the People's Republic of China, 2010). The protein content was calculated using 6.25 as a conversion factor. Total lipid content (\%) was determined by exhaustive Soxhlet extraction (AOAC methods, 2012). Total carbohydrate was evaluated using the difference: Total carbohydrates, $\%=100-($ moisture, $\%+$ ash, $\%+$ protein, $\%$ + lipids, \%). The nutritional value of Sorbus aria fruit was calculated (Petkova et al., 2020).

Preparation of fruit extracts. The extraction procedure was performed in a solid to liquid ratio 1:5 (w/v) with acetone (for pigments), 95\% ethanol (for phenolic compound and antioxidant activity) and distilled water (for sugar analysis) in an ultrasonic bath (VWR, Malaysia) with frequency $45 \mathrm{kHz}$ and $30 \mathrm{~W}$ power at $45^{\circ} \mathrm{C}$ in triplicate (Petkova et al., 2020).

HPLC-RID of sugars. Sugar analysis was performed on an HPLC instrument Elite Chrome Hitachi with a refractive index detector (RID) Chromaster 5450 on a Shodex ${ }^{\circledR}$ Sugar SP0810 $(300 \mathrm{~mm} \times 8.0 \mathrm{~mm})$ with $\mathrm{Pb}^{2+}$ and a guard column Shodex SP $-\mathrm{G}(5 \mu \mathrm{m}, 6 \times 50$ $\mathrm{mm}$ ) at $85^{\circ} \mathrm{C}$, mobile phase distilled $\mathrm{H}_{2} \mathrm{O}$ with a flow rate of $1.0 \mathrm{ml} / \mathrm{min}$ (Petkova et al., 2014).

Sweetness. Sweetness index (SI) and Total sweetness index (TSI) were calculated after HPLC analysis of individual sugars for determination of the fruit sweetness perception (Akšić et al., 2019). Sweetness Index - SI was calculated, based on the fact that fructose and sucrose are 2.30 and 1.35 times sweeter than glucose, respectively: $\mathrm{SI}=(1.00 \times$ [glucose] $)+(2.30$ $\times$ [fructose $])+(1.35 \times$ [sucrose] $)$. Total sweetness index - TSI is expressed with the contribution of each sugar estimated relative to sucrose: TSI $=(1.00 \times[\mathrm{su}-$ crose $])+(0.76 \times[$ glucose $])+(1.50 \times[$ fructose $])$.

Pectin (uronic acids) content. The uronic acid content of the fruit material was determined as described
(Ahmed and Labavitch, 1978). Before analysis, the sample was solubilized with $72 \%(w / w) \mathrm{H}_{2} \mathrm{SO}_{4}$ for $1 \mathrm{~h}$ at $30^{\circ} \mathrm{C}$, followed by hydrolysis step with $1 \mathrm{M} \mathrm{H}_{2} \mathrm{SO}_{4}$ for $3 \mathrm{~h}$ at $100^{\circ} \mathrm{C}$. An aliquot of hydrolyzate was used for analysis by $m$-hydroxydiphenyl assay using galacturonic acid as a standard (Blumenkrantz and Asboe-Hansen, 1973).

Pigments. The total chlorophylls and carotenoids were extracted with acetone. The absorbance of the samples was measured at three wavelengths 662,645 , and 470 $\mathrm{nm}$ (Lichtenthaler and Wellburn, 1983) using UV/Vis spectrophotometer Camspec M107 (Spectronic-Camspec Ltd., Leeds, UK). Lycopene and $\beta$-carotene were extracted in triplicate with 50,30 and $30 \mathrm{ml}$ acetone, respectively for $20 \mathrm{~min}$ in the dark, and the extract was filtered. The combined acetone extracts were added to a separating funnel, then petroleum ether $(75 \mathrm{ml})$ was added, and the organic phase was washed three times with $50 \mathrm{ml}$ water. The remaining water was removed with anhydrous sodium sulfate and the volume was made up to $100 \mathrm{ml}$ with petroleum ether. The absorptions at 450 and $503 \mathrm{~nm}$ were measured and the concentrations of lycopene and $\beta$-carotene were calculated (Lime et al., 1957). Total anthocyanin content was determined according to the $\mathrm{pH}$ differential method (AOAC 2005.02). The samples $(0.5 \mathrm{ml})$ were mixed with buffers at $\mathrm{pH} 1.0$ and $\mathrm{pH} 4.5(2.5 \mathrm{~mL})$, and the absorbance was measured against a blank at $\lambda$ $=510$ and $700 \mathrm{~nm}$. The results were expressed in $\mathrm{mg}$ cyanidin-3-glycoside equivalents / $100 \mathrm{~g}$.

Total phenols and flavonoids content. The fruit extract $(0.2 \mathrm{ml})$ was mixed with $1 \mathrm{ml}$ of five-time diluted Folin-Ciocalteu reagent and $0.8 \mathrm{ml}$ of $7.5 \% \mathrm{Na}_{2} \mathrm{CO}_{3}$. After 20 min the absorbance was measured at $765 \mathrm{~nm}$ against a blank sample. The results were expressed as mg equivalent of gallic acid (GAE) per $g$ fresh and dry weight. The total flavonoids content was analyzed colorimetrically using $\mathrm{Al}\left(\mathrm{NO}_{3}\right)_{3}$ reagents. The extract $(0.5 \mathrm{~mL})$ was added to plastic test tubes, then $0.1 \mathrm{~mL}$ $10 \%$ aluminum nitrate, $0.1 \mathrm{~mL} 1 \mathrm{M}$ potassium acetate and $3.8 \mathrm{~mL} 95 \%$ ethanol were added. After $40 \mathrm{~min}$ at an ambient temperature, the absorbance was measured at $415 \mathrm{~nm}$ against a control sample prepared using the above-mentioned procedure without the addition of $0.1 \mathrm{~mL} 10 \%$ aluminum nitrate. The absorbance was 
Petkova, N. Tr., Ognyanov, M. H., Vrancheva, R. Z., Zhelev, P. (2020). Phytochemical, nutritional and antioxidant characteristics of whitebeam (Sorbus aria) fruits. Acta Sci. Pol. Technol. Aliment., 19(2), 219-229. http://dx.doi.org/10.17306/J.AFS.2020.0786

measured at $415 \mathrm{~nm}$ against a blank. The results were expressed as mg equivalents quercetin $(\mathrm{QE})$ per g dry and fresh weight (Ivanov et al., 2014).

Phenolic acid content. Phenolic acids were analyzed using a Elite LaChrome (Hitachi) HPLC system equipped with a diode array detector, ELITE LaCHrome (Hitachi) software and a column Supelco Discovery HS C18 column $(5 \mu \mathrm{m}, 25 \mathrm{~cm} \times 4.6 \mathrm{~mm})$, operating at $30^{\circ} \mathrm{C}$ under gradient conditions with a mobile phase consisting of $2 \%(\mathrm{v} / \mathrm{v})$ acetic acid (solvent A) and acetonitrile (solvent B) with a flow rate $0.8 \mathrm{ml} /$ min (Terzieva et al., 2017).

\section{Antioxidant activity}

DPPH radical-scavenging ability. The ethanolic extract $(0.15 \mathrm{ml})$ was mixed with $2.85 \mathrm{ml}$ fresh $0.1 \mathrm{mM}$ methanol solution of DPPH. The sample was incubated at $37^{\circ} \mathrm{C}$ in darkness for $15 \mathrm{~min}$. The reduction of absorbance was measured at $517 \mathrm{~nm}$ against a blank and \% inhibition was calculated (Ivanov et al., 2014).

ABTS $^{+}$radical scavenging ability. The $\mathrm{ABTS}^{+}$solution $(2.85 \mathrm{ml})$ was mixed with $0.15 \mathrm{ml}$ extracts. After $15 \mathrm{~min}$ at $37^{\circ} \mathrm{C}$ in darkness, the absorbance was measured at $734 \mathrm{~nm}$ against ethanol (Ivanov et al., 2014).

FRAP assay. The FRAP reagent was prepared before analysis by mixing 10 parts $0.3 \mathrm{M}$ acetate buffer (pH 3.6), 1 part $10 \mathrm{mM} \mathrm{2,4,6-tri(2-pyridyl)-s-triazine}$ (TPTZ) in $40 \mathrm{mM} \mathrm{HCl}$ and 1 part $20 \mathrm{mM} \mathrm{FeCl}_{3} \cdot 6 \mathrm{H}_{2} \mathrm{O}$ in distilled water. FRAP reagent $(3.0 \mathrm{ml})$ was mixed with $0.1 \mathrm{ml}$ extract. After $10 \mathrm{~min}$ at $37^{\circ} \mathrm{C}$ in darkness, the absorbance of the sample was measured at $593 \mathrm{~nm}$ (Ivanov et al., 2014).

CUPRAC assay. Sample $(0.1 \mathrm{ml})$ was mixed with $1 \mathrm{ml} \mathrm{CuCl} \times 2 \mathrm{H}_{2} \mathrm{O}, 1 \mathrm{ml}$ methanol solution of Neocuproine, $1 \mathrm{ml} 0.1 \mathrm{M}$ ammonium acetate buffer and $1 \mathrm{ml}$ distilled $\mathrm{H}_{2} \mathrm{O}$. After $20 \mathrm{~min}$ at $50^{\circ} \mathrm{C}$ in darkness, the samples were cooled to room temperature and the absorbance was measured at $450 \mathrm{~nm}$.

All the results from the determination of antioxidant activity were performed in triplicates and expressed as mM Trolox equivalents (mM TE) on fresh weight (fw) and dry weight (dw) (Ivanov et al., 2014).
Statistical analysis. All analyses were performed in triplicate $(n=3)$. The data were presented as mean values \pm standard deviation (SD). Statistical analysis was performed using MS Excel 2010.

\section{RESULTS AND DISCUSSION}

\section{Nutritional characteristics of common whitebeam (Sorbus aria) fruit}

The detailed phytochemical composition and nutritional properties of edible parts of common whitebeam fruit are summarized in Table 1.

The moisture content of Sorbus aria fruit was $54.50 \pm 0.15 \%$, while the total dry weight was 45.50 $\pm 0.15 \%$, respectively. Its moisture content was close to the values (56-60\%) of other Sorbus aria collected from Vitosha Mountain and was lower than samples from Rila and Rhodopi mountains (60-70\%) (Michev et al., 1983). Ash content was $2.53 \pm 0.17 \%$ and it was near to values found in the samples from Rila Mountain (Michev et al., 1983). The protein content of Sorbus aria fruit was found in relatively low amounts $(1.48 \pm 0.31 \%)$, which was comparable with other whitebeam fruit (Michev et al., 1983) - 0.6 to $1.8 \%$ fw. Moreover, protein content coincided with this in Sea-buckthorn fruit (Zenkova and Pinchykova, 2019), peaches, and cherries $-1 \mathrm{~g}$ per $100 \mathrm{~g}$ (Sikora et al., 2013). The fruit were characterized by a low lipid content of $1.00 \pm 0.20 \mathrm{~g} / 100 \mathrm{~g}$ (fresh weight) and $2.22 \pm 0.20 \%$ (dry weight), respectively. Michev et al. (1983) reported that total lipid content expressed as ether extract was in the range $0.5-1.85 \%$ for other Sorbus aria fruit. The lipid content of whitebeam fruit was lower than that of Sea-buckthorn fruit $-6.20-3.60 \%$ (Zenkova and Pinchykova, 2019), but higher in Malus baccata $-0.55 \pm 0.05 \% \mathrm{dw}$ (Petkova et al., 2020).

Carbohydrates were the main constituents of the common whitebeam fruit, reaching $38.54 \mathrm{~g} / 100 \mathrm{~g}$ of fresh weight, as the soluble sugars represented $18 \%$ of them. Sucrose was not detected in the water extract, which was in agreement with the findings on 18 Sorbus cultivars (Zymone et al., 2018). Fructose and glucose were the only monosaccharides found in the extract (Fig. 1; 2.73 and $3.63 \mathrm{~g} / 100 \mathrm{~g}$ fw).

Interestingly, our results for glucose and fructose, as well as for total sugar content $(6.36 \mathrm{~g} / 100 \mathrm{~g} \mathrm{fw})$, were comparable to those in other studies on forest fruits, 
Petkova, N. Tr., Ognyanov, M. H., Vrancheva, R. Z., Zhelev, P. (2020). Phytochemical, nutritional and antioxidant characteristics of whitebeam (Sorbus aria) fruits. Acta Sci. Pol. Technol. Aliment., 19(2), 219-229. http://dx.doi.org/10.17306/J.AFS.2020.0786

Table 1. Nutritional characteristics of Sorbus aria fruit grown in Bulgaria

\begin{tabular}{lcc}
\hline \multicolumn{1}{c}{ Characteristics } & Fresh weight & Dry weight \\
\hline Moisture, \% & $54.50 \pm 0.15$ & \\
Dry matter, \% & $45.50 \pm 0.15$ & $5.61 \pm 0.17$ \\
Ash content, \% & $2.53 \pm 0.17$ & $0.98 \pm 0.02$ \\
Titrable acidity (TA), \% & $0.44 \pm 0.02$ & $4.32 \pm 0.05$ \\
pH & $4.22 \pm 0.05$ & $2.22 \pm 0.20$ \\
Lipids, g/100 g & $1.00 \pm 0.20$ & $3.29 \pm 0.31$ \\
Proteins, g/100 g & $1.48 \pm 0.31$ & $85.56 \pm 2.05$ \\
Carbohydrates, g/100 g & $38.54 \pm 2.05$ & $6.06 \pm 0.04$ \\
Glucose, g/100 g & $2.73 \pm 0.04$ & $8.06 \pm 0.02$ \\
Fructose, g/100 g & $3.63 \pm 0.02$ & not detected \\
Sucrose, g/100 g & not detected & $14.12 \pm 0.02$ \\
Total reducing sugars, $\mathrm{g} / 100 \mathrm{~g}$ & $6.36 \pm 0.02$ & $24.60 \pm 0.02$ \\
Sweetness index (SI) & $11.08 \pm 0.02$ & $16.69 \pm 0.02$ \\
Total sweetness index $(\mathrm{TSI})$ & $7.52 \pm 0.02$ & $14.54 \pm 0.02$ \\
Total sugars / TA ratio & $14.54 \pm 0.02$ & $3.90 \pm 0.02$ \\
Pectin $(\mathrm{expressed} \mathrm{as} \mathrm{uronic} \mathrm{acids),} \mathrm{g/100} \mathrm{g}$ & $1.77 \pm 0.02$ & $375(1569)$ \\
Caloric value, kcal/100 g (kJ/100 g) & $169(707)$ & \\
\hline
\end{tabular}

Values are reported as mean $\pm \mathrm{SD}$ from a triplicate determination.

such as bird cherry (Padus avium Mill.), mountain-ash (Sorbus aucuparia L.) (Sergunova and Bokov, 2019), blackthorn (Prunus spinosa L.) (Sikora et al., 2013), some Sorbus cultivar (Zymone et al., 2018), blueberry (Akšić et al., 2019), blackberry, strawberry, wild-grown elderberry and goji berry (Mikulic-Petkovsek et al., 2012). Sweetness Index - SI was 11.08, while TSI was 7.52 (Table 1). Our values for SI were comparable to those of strawberries $-10.13 \pm 0.63$ (Keutgen and Pawelzik, 2007). The taste of $S$. aria depends on individual sugars - glucose and fructose. The highest concentration of fructose in common whitebeam fruit had the highest impact on the sweetness of the fruit. The absence of sucrose in ripe common whitebeam fruit makes them recommendable for use in dietetic nutrition. This fruit should be promoted in low carbohydrate diets.

Organic acids, sugars, and their ratio determine the organoleptic properties of the fruit. Titrable acidity expressed as malic acid did not exceed $0.9 \%$ (Table 1 ), which was comparable with results reported for common whitebeam and strawberry fruit (Keutgen and Pawelzik, 2007; Michev et al., 1983). Also, organic acids are crucial for the processing of fruit, due to their influence on the gelling properties of pectins. Sugar to acid ratio is defined as the total sugar content compared to the total acid level. This sugar/acid ratio is responsible for the taste and flavor of fruit. It is also an indicator of commercial and sensory ripeness. Sugar/ organic acid ratios, which ranged from 3 to 9 in the fruit, were described as having a sweet-sour or soursweet taste (Mikulic-Petkovsek et al., 2012). In our study, whitebeam fruit had a high sugar/organic acid ratio -14.54 , which is above 5 , and therefore its fruit might be considered sweet ones according to Zymone et al. (2018). The calculated ratio showed that Sorbus aria fruit were comparable with values reported for 
Petkova, N. Tr., Ognyanov, M. H., Vrancheva, R. Z., Zhelev, P. (2020). Phytochemical, nutritional and antioxidant characteristics of whitebeam (Sorbus aria) fruits. Acta Sci. Pol. Technol. Aliment., 19(2), 219-229. http://dx.doi.org/10.17306/J.AFS.2020.0786

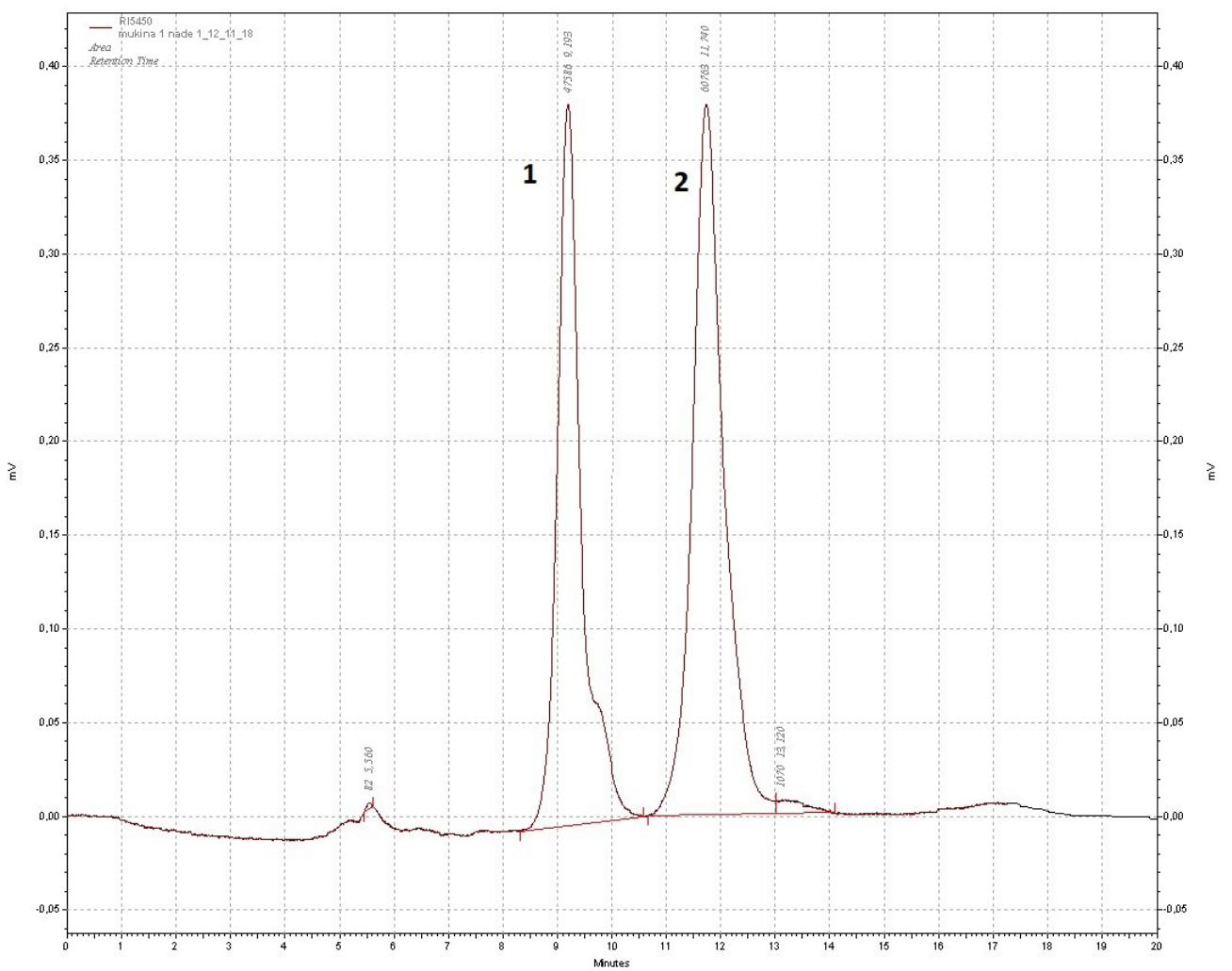

Fig. 1. HPLC-RID chromatogram of the aqueous extract from Sorbus area fruit: 1 - glucose, 2 - fructose

other fruit like some Sorbus aucuparia cultivar, 'Businka', Eastern shadbush and black mulberry - with total sugars / TA ratio of $14.39,13.56$ and 12.91 , respectively (Mikulic-Petkovsek et al., 2012; Zymone et al., 2018).

Another valuable component detected in Sorbus aria fruit was uronic acids, which represent the amount of an acidic polysaccharide such as pectin $1.77 \pm 0.02 \mathrm{~g} / 100 \mathrm{~g}$ fw. They accounted for $5 \%$ of the total carbohydrates in the fruit (Table 1). These values were higher than the results reported for other representatives from the Bulgarian mountains (Michev et al., 1983), and Sea buckthorn berry (Zenkova and Pinchykova, 2019). Pectin is a valuable soluble dietary fiber that is widely used in the food industry due to its thickening and gelling properties. Therefore, these fruit presented a low caloric natural source of dietary fiber and they could be successfully used for the preparation of jams, jelly, fillings, and marmalade.
Keeping in mind the energy factor for different constituents, the caloric value of Sorbus aria fruits was calculated (Table 1). It was $169 \mathrm{kcal} / 100 \mathrm{~g}$ in fresh fruit and $375 \mathrm{kcal} / 100 \mathrm{~g}$ in dried fruit, respectively. The energy values are $17 \mathrm{~kJ} / \mathrm{g}(4.0 \mathrm{kcal} / \mathrm{g})$ for protein, $37 \mathrm{~kJ} / \mathrm{g}(9.0 \mathrm{kcal} / \mathrm{g})$ for fat, and $17 \mathrm{~kJ} / \mathrm{g}(4.0 \mathrm{kcal} / \mathrm{g})$ for carbohydrates. Based on the calculation of the total energy intake, which is $375 \mathrm{kcal} / 100 \mathrm{~g} \mathrm{dw}$, it can be emphasized that carbohydrates give the highest percentage of energy $(>90 \%)$, while lipids bring less than $10 \%$ of the total energy intake. Based on the energy factor for available carbohydrates expressed as monosaccharides, it was calculated that they do not account for more than of $15 \%$ of the total caloric values (53 $\mathrm{kcal} / 100 \mathrm{~g}$ ). Therefore, a significant impact on caloric value is due to pectin, starch, and cellulose and other fermentable fibers $(289 \mathrm{kcal} / 100 \mathrm{~g} \mathrm{dw})$. Furthermore, according to a report by FAO (2003), dietary fiber should be adopted in energy evaluation. Each dietary 
Petkova, N. Tr., Ognyanov, M. H., Vrancheva, R. Z., Zhelev, P. (2020). Phytochemical, nutritional and antioxidant characteristics of whitebeam (Sorbus aria) fruits. Acta Sci. Pol. Technol. Aliment., 19(2), 219-229. http://dx.doi.org/10.17306/J.AFS.2020.0786

fiber has an energy value which depends on its fermentability, so an energy conversion factor of $2 \mathrm{kcal} / \mathrm{g}$ should be used in our case. Of these, pectin accounts for no more than $3 \%$ of the total energy intake.

\section{Natural pigments}

Natural pigments detected in Sorbus aria fruit in the fresh state were presented. Total chlorophylls were $5.12 \mu \mathrm{g} / \mathrm{g} \mathrm{fw}$, while total carotenoids were 3 times more $-16.91 \mu \mathrm{g} / \mathrm{g}$ fw (Table 2). An additional comparison was made between Bulgarian and other Sorbus aria representatives from the Balkan Peninsula (Table 2)

Chlorophylls a and b were also detected in S. aria fruit as the mean values of $0.61 \mu \mathrm{g} / \mathrm{g} \mathrm{dw}$ for chlorophyll $a$, and $0.43 \mu \mathrm{g} / \mathrm{g} \mathrm{dw}$ for chlorophyll $b$ (Šavikin et al., 2017). However, in S. aria fruit from Bulgaria, the values of these pigments were from 6 to 18 times higher than those in Serbian samples.

The total carotenoid content in common whitebeam fruit was higher than the chlorophyll content $(16.91 \pm 0.68 \mu \mathrm{g} / \mathrm{g}$ fw and $37.17 \pm 0.68 \mu \mathrm{g} / \mathrm{g} \mathrm{dw})$. $\beta$-Carotene and lycopene were the main carotenoids detected in fruit samples, as their total content $(11.68 \mu \mathrm{g} / \mathrm{g} \mathrm{fw})$ presented $69 \%$ of the total carotenoids (Table 2). In a study carried out by O'Sullivan et al. (2011), it was reported that $\beta$-carotene was the predominant carotenoid in Irish whitebeam, rosehips, and rowanberries (52 to $73 \mu \mathrm{g} / 100 \mathrm{~g}$ sample). However, in our study, lycopene was found to be a major carotenoid constituent in $S$. aria fruit. The presence of lycopene in common whitebeam fruit was also reported by Šavikin et al. (2017). Moreover, its content in the Bulgarian representative was significantly higher in comparison with Serbian fruit. In addition, O Sullivan et al. (2011) reported that whitebeam also contained $\beta$-cryptoxanthin $(10 \mu \mathrm{g} / 100 \mathrm{~g}$ sample). The presence of lutein and $\alpha$-carotene was found in fruits collected from Serbia and Montenegro (Šavikin et al., 2017). Interestingly, the total carotenoid content $(16.91 \mu \mathrm{g} /$ fw and $37.17 \mu \mathrm{g} / \mathrm{dw}$ ) found in the current study was higher than the total carotenoid content in service tree (Sorbus domestica) - $0.29 \mathrm{mg} / 100 \mathrm{~g}$ fw (Egea et al., 2010) and more than 10 times lower in rowanberries (Zymone et al., 2018). We did not detect any monomeric anthocyanidins in the fruit of S. aria (Table 2). The absence of monomeric anthocyanidins was found for the fruit of crab apple (Petkova et al., 2020).

\section{Total phenol and total flavonoid content}

The phenolic content, flavonoid content, and the content of phenolic acids, which was determined individually, are summarized in Table 3.

The phenolic content in common whitebeam berries was $32.42 \pm 2.72$ and $71.25 \pm 2.72 \mathrm{mg} \mathrm{GAE} / 100 \mathrm{~g}$ fresh and dry weight, respectively. The total flavonoids were twice lower than the content of total phenols

Table 2. Chlorophyll and carotenoid contents in common whitebeam fruit collected from the Balkan Peninsula

\begin{tabular}{lcccc}
\hline \multirow{2}{*}{ Pigments } & \multicolumn{2}{c}{ In this study (in Bulgaria) } & In Serbia & In Montenegro \\
\cline { 2 - 4 } & $\mu \mathrm{g} / \mathrm{g} \mathrm{dw}$ fw & $\mu \mathrm{g} / \mathrm{g} \mathrm{dw}$ & $\mu \mathrm{g} / \mathrm{g} \mathrm{dw}$ & $\mu \mathrm{g} / \mathrm{g} \mathrm{dw}$ \\
\hline Chlorophyll $a$ & $1.63 \pm 0.12$ & $3.58 \pm 0.12$ & $0-1.20$ & $0.66-1.18$ \\
Chlorophyll $b$ & $3.48 \pm 0.18$ & $7.65 \pm 0.18$ & $0.07-1.91$ & $0.31-0.54$ \\
Chlorophyll $a / b$ ratio & $0.56 \pm 0.16$ & $0.56 \pm 0.16$ & not reported & not reported \\
Total chlorophyll $(a+b)$ & 5.12 & 11.25 & not reported & not reported \\
Total carotenoids & $16.91 \pm 0.68$ & $37.17 \pm 0.68$ & not reported & not reported \\
$\beta$-carotene & $5.38 \pm 0.21$ & $11.82 \pm 0.21$ & $0.04-0.88$ & $0.19-1.11$ \\
Lycopene & $6.30 \pm 0.11$ & $13.85 \pm 0.11$ & $0.19-0.61$ & $0.06-0.13$ \\
Total monomeric anthocyanidins & not detected & not detected & not reported & not reported \\
\hline
\end{tabular}

Values are reported as mean $\pm \mathrm{SD}$ from a triplicate determination. 
Petkova, N. Tr., Ognyanov, M. H., Vrancheva, R. Z., Zhelev, P. (2020). Phytochemical, nutritional and antioxidant characteristics of whitebeam (Sorbus aria) fruits. Acta Sci. Pol. Technol. Aliment., 19(2), 219-229. http://dx.doi.org/10.17306/J.AFS.2020.0786

(44.13 $\pm 0.42 \mathrm{mg} \mathrm{QE} / 100 \mathrm{~g} \mathrm{dw})$. Comparable to our findings, O`Sullivan et al. (2011) reported a lower level of total phenols $(20 \mathrm{mg} \mathrm{GAE} / 100 \mathrm{ml})$ in Irish whitebeam fruit. Our values for the total phenols were lower compared with the reported values for other Sorbus spp. (American mountain-ash, Sorbus americana) $154.8 \pm 3.3 \mathrm{mg} \mathrm{GAE} / \mathrm{g} \mathrm{dw}$ and European rowanberry (Sorbus aucuparia) $39.6 \pm 1.4 \mathrm{mg} \mathrm{GAE} / \mathrm{g} \mathrm{dw}$ (Klensporf-Pawlik and Przybylski, 2015), and Serbian common whitebeam berries - 3.91-10.81 mg GAE/g $\mathrm{dw}$ (Šavikin et al., 2017). The data for total flavonoid content in Sorbus aria in our study was comparable with the reported values of flavonoid aglycone content 20-31 mg/100 g dw (Olszewska, 2008).

The content of phenolic acids is presented in Table 3. Four phenolic acids were detected as their content decreased in the following order: 2,4-dihydrohybenzoic acid $>$ sinapic acid $>p$-coumaric acid $>$ caffeic acid. It was easy to recognize 2,4-dihydrohybenzoic acid as the main constituent in common whitebeam fruit with values of $108.01 \pm 0.05 \mu \mathrm{g} / \mathrm{g}$ fw and $237.38 \pm 0.05 \mu \mathrm{g} / \mathrm{g} \mathrm{dw}$, respectively. Moreover, gallic acid, chlorogenic acid, ferulic acid, cinnamic acid, and chicoric acid were not detected. However, in Sorbus aria fruit collected from Serbia and Montenegro, only two phenolic acids were detected, as chlorogenic acid ranged from $0.22-2.30 \mathrm{mg} / \mathrm{g} \mathrm{dw}$, while neochlorogenic acid varied from 0.18 to $4.00 \mathrm{mg} / \mathrm{g}$ dw (Šavikin et al., 2017). Contrary to Sorbus aucuparia, where chlorogenic (29-160 mg) and neochlorogenic (34-104 mg) acids constituted the major fraction in all rowanberries (Hukkanen et al., 2006), in the case of Sorbus aria, 2,4-dihydrohybensoic acid, sinapic acid, and $p$-coumaric acid were the dominating phenolic acids in its fruit. Chlorogenic acid was absent from Sorbus aria fruit collected from Bulgaria. This is the first study that has examined the phenolic acid content and composition of Sorbus aria fruit collected from Bulgaria.

The difference in phenolic and natural pigment content of Sorbus aria can be explained with the different environmental and growing conditions. The samples collected at an altitude above $800 \mathrm{~m}$ were grown in severe conditions, which led to an increase in the production of more phenolic components. Michev et al. (1983) also mentioned that altitude influences the chemical composition of common whitebeam fruit from the Bulgarian mountains (Vitosha, Rila, and Rhodopi), especially moisture content.

Table 3. Phenolic acid composition, total phenolic content and flavonoid content of common whitebeam fruit

\begin{tabular}{lcc}
\hline \multicolumn{1}{c}{ Characteristics } & Content for fresh weight & Content for dry weight \\
\hline 2,4-dihydrohybensoic acid & $108.01 \pm 0.05$ & $237.38 \pm 0.05$ \\
Gallic acid & n.d. & n.d. \\
Chlorogenic acid & n.d. & $58.29 \pm 0.12$ \\
Caffeic acid & $26.52 \pm 0.12$ & n.d. \\
Ferulic acid & n.d. & $145.65 \pm 0.20$ \\
$p$-coumaric acid & $66.27 \pm 0.20$ & $179.71 \pm 0.18$ \\
Sinapic acid & $81.77 \pm 0.18$ & n.d. \\
Cinnamic acid & n.d. & n.d. \\
Chicoric acid & n.d. & $621.03 \pm 0.32$ \\
Total phenolic acids, $\mu \mathrm{g} / \mathrm{g}$ & $282.57 \pm 0.32$ & $71.25 \pm 2.72$ \\
Total phenolic compounds, $\mathrm{mg}$ GAE/100 g & $32.42 \pm 2.72$ & $44.13 \pm 0.42$ \\
Total flavonoids, $\mathrm{g} g \mathrm{QE} / 100 \mathrm{~g}$ & $20.08 \pm 0.42$ & \\
\hline
\end{tabular}

Values are reported as mean $\pm \mathrm{SD}$ from a triplicate determination, n.d. - not detected. 


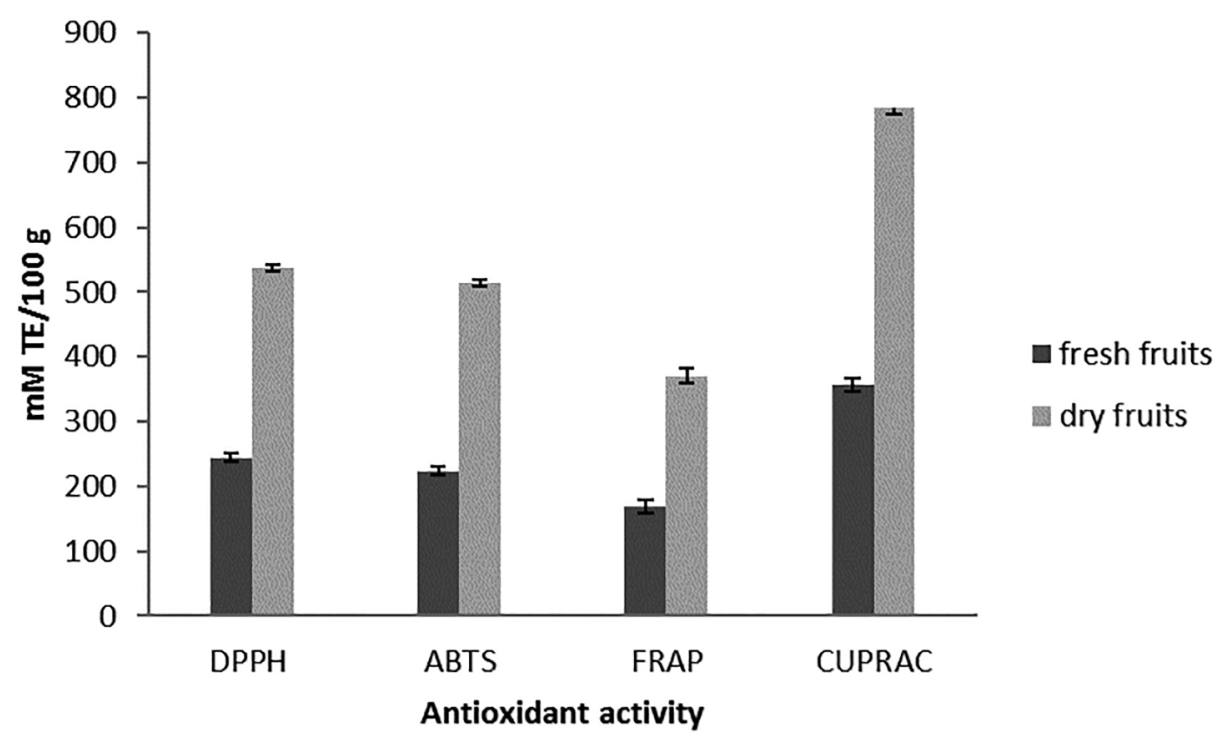

Fig. 2. Antioxidant activity of common whitebeam fruit

\section{Antioxidant activity}

To the best of our knowledge, this is the first detailed study with an evaluation of the antioxidant potential of Sorbus aria fruit. Several methods have been developed to evaluate antioxidant activity, using the scavenging of synthetic or generated radicals. In our study, four methods, based on two different mechanisms - SET (single electron transfer) and HAT-type (hydrogen atom transfer) - were used to evaluate the antioxidant activity of Sorbus aria fruit collected from Bulgaria (Fig. 2).

The antioxidant potential of fresh fruit was in the range from 168.52 (FRAP) to $356.34 \mathrm{mM} \mathrm{TE} / 100 \mathrm{~g} \mathrm{fw}$ (CUPARC) and from 370.70 to $783.17 \mathrm{mM} \mathrm{TE} / 100 \mathrm{~g}$ dw. Therefore, the fruit demonstrated antioxidant activity by both SET and HAT mechanisms. It was found that the common whitebeam fruit exhibited the highest cupper reducing properties (CUPRAC assay), followed by radical scavenging properties, evaluated using DPPH and ABTS assays (Fig. 2). The obtained values for the antioxidant activity for common whitebeam fruit (Sorbus aria) were higher than reported in literature data for 20 Sorbus cultivar (Zymone et al., 2018), Sorbus domestica (Akšić et al., 2019), and blackthorn fruit (Sikora et al., 2013). The demonstrated antioxidant activity of Sorbus aria fruit revealed its application as a possible antioxidant ingredient for nutraceutical or functional food. In addition, the low sugar content and absence of sucrose together with the high phenolic content in Sorbus aria fruit revealed the potential of these fruit for application in diets. The presence of phytochemicals is important for controlling obesity and diabetes, as reported previously in detail (Mihaylova et al., 2018).

\section{CONCLUSION}

In the current study, fruits of the common whitebeam (Sorbus aria) were characterized as a natural source of phytonutrients such as pectin, carotenoids, phenolic acids, and flavonoids. The nutritional and antioxidant properties of the fruit demonstrated their potential for the preparation of foods with potential beneficial effects, as well as low caloric foods and dietary supplements. Due to a rich phenolic acid content, high antioxidant potential, and low sugar content the investigated fruit could be included in diets for healthy and dietetic nutrition.

\section{REFERENCES}

Ahmed, A. E. R., Labavitch, J. M. (1978). A simplified method for accurate determination of cell wall uronide content. J. Food Biochem., 1, 361-365. https://doi. org/10.1111/j.1745-4514.1978.tb00193.x 
Petkova, N. Tr., Ognyanov, M. H., Vrancheva, R. Z., Zhelev, P. (2020). Phytochemical, nutritional and antioxidant characteristics of whitebeam (Sorbus aria) fruits. Acta Sci. Pol. Technol. Aliment., 19(2), 219-229. http://dx.doi.org/10.17306/J.AFS.2020.0786

Akšić, M. F., Tosti, T., Sredojević, M., Milivojević, J., Meland, M., Natić, M. (2019). Comparison of sugar profile between leaves and fruits of blueberry and strawberry cultivars grown in organic and integrated production system. Plants, 8, 205. https://doi.org/10.3390/ plants8070205

AOAC (2007). Official methods of analysis, 18th ed. Arlington, VA, USA: Association of Official Analytical Chemists. http://www.eoma.aoac.org/methods/info. asp? ID $=21670$

Blumenkrantz, N., Asboe-Hansen, G. (1973). New method for quantitative determination of uronic acids. Anal. Biochem., 54, 484-489. https://doi.org/10.1016/00032697(73)90377-1

Bradstreet, R. B. (1965). The Kjeldahl method for organic nitrogen. New York, USA: Academic Press.

Egea, I., Sánchez-Bel, P., Romojaro, F., Pretel, M. T. (2010). Six edible wild fruits as potential antioxidant additives or nutritional supplements. Plant Foods Hum. Nutr., 65(2), 121-129. https://doi.org/10.1007/s11130-010-0159-3

FAO Food and Nutrition Paper 77 (2003). Food energy methods of analysis and conversion factors. Rome: Food and Agriculture Organization of the United Nations.

Hukkanen, A. T., Polonen, S. S., Karenlampi, S. O., Kokko, H. I. (2006). Antioxidant capacity and phenolic content of sweet rowanberries. J. Agric. Food Chem., 54, 112119. https://doi.org/10.1021/jf051697g

Ivanov, I. R., Vrancheva, A., Marchev, N., Petkova, I., Aneva, P., Denev, V., ..., Pavlov, A. (2014). Antioxidant activities and phenolic compounds in Bulgarian Fumaria species. IJCMAS, 3(2), 296-306.

Keutgen, A. J., Pawelzik, E. (2007). Modifications of tasterelevant compounds in strawberry fruit under $\mathrm{NaCl}$ salinity. Food Chem., 105, 1487-1494. https://doi. org/10.1016/j.foodchem.2007.05.033

Klensporf-Pawlik, D., Przybylski, R. (2015). Antioxidant activity of selected wild Canadian prairie fruits. Acta Sci. Pol. Technol. Aliment., 14(4), 357-366. https://doi. org/10.17306/J.AFS.2015.4.35

Lichtenthaler, H. K., Wellburn, A. R. (1983). Determination of total carotenoids and chlorophylls $a$ and $b$ of leaf in different solvents. Biochem. Soc. Trans., 11(5), 591592. https://doi.org/10.1042/bst0110591

Lime, B. J., Griffiths, F. P., O’Connor, R. T., Heinzelman, D. C., McCall, E. R. (1957). Grapefruit pigment determination, spectrophotometric methods for determining pigmentation-beta-carotene and lycopene-in ruby red grapefruit. J. Agric. Food Chem., 5(12), 941-944. https://doi.org/10.1021/jf60082a008
Mikulic-Petkovsek, M., Schmitzer, V., Slatnar, A., Stampar, F., Veberic, R. (2012). Composition of sugars, organic acids, and total phenolics in 25 wild or cultivated berry species. J. Food Sci., 77(10), C1064-C1070. https://doi. org/10.1111/j.1750-3841.2012.02896.x

Michev, B., Najdenov, A., Chortalova, S., Malinov, T. (1983). Gorskite plodove hrana i lechebno sredstvo [Forest fruits food and medicical tool]. Sofia, Bulgaria: Zamizdat Press [in Bulgarian].

Mihaylova, D., Popova, A., Alexieva, I., Krastanov, A., Lante, A. (2018). Polyphenols as suitable control for obesity and diabetes. Open Biotechnol. J., 12, 219-228, https:// doi.org/10.2174/1874070701812010219

National Food Safety Standard of the People's Republic of China (2010). Determination of protein in foods. GB 5009.5-2010.

O’Sullivan, A. M., O’Callaghan, Y. C., O’Connor, T. P., O'Brien, N. M. (2011). Bioaccessibility of polyphenol and carotenoid from wild Irish berries subjected to in vitro digestion procedure. Proc. Nutr. Soc., 70, E61. https://doi.org/10.1017/S0029665111001017

Olszewska, M. A. (2008). Separation of quercetin, sexangularetin, kaempferol and isorhamnetin for simultaneous HPLC determination of flavonoid aglycones in inflorescences, leaves and fruits of three Sorbus species. J. Pharm. Biomed. Anal., 48, 629-635. https://doi. org/10.1016/j.jpba.2008.06.004

Olszewska, M. A., Michel, P. (2012). Activity-guided isolation and identification of free radical scavenging components from various leaf extracts of Sorbus aria (L.) Crantz., Nat. Prod. Res., 26(3), 243-254. http://dx.doi. org/10.1080/14786419.2010.537271

Petkova, N., Ognyanov, M., Inyutin, B., Zhelev, P., Denev, P. (2020). Phytochemical composition and antioxidant activity of Malus baccata (L.) Borkh. fruits. FSAB, 3(1), 47-55. https://doi.org/10.30721/fsab2020.v3.i1.46

Petkova, N., Vrancheva, R., Denev, P., Ivanov, I., Pavlov, A. (2014). HPLC-RID method for determination of inulin and fructooligosacharides. ASN, 1, 99-107.

Šavikin, K. P., Zdunić, G. M., Krstić-Milošević, D. B., Šircelj, H. J., Stešević, D. D., Pljevljakušić, D. S. (2017). Sorbus aucuparia and Sorbus aria as a source of antioxidant phenolics, tocopherols and pigments. Chem. Biodivers., 14(12), e1700329. https://doi.org/10.1002/ cbdv.201700329

Sergunova, E. V., Bokov, D. O. (2019). Some pharmacognostic studies of the bird cherry (Padus avium Mill.) and mountain ash (Sorbus aucuparia L.) fruits collected from Moscow (Russia), Pharmacog. J., 11(5), 996-1002, https://doi.org/10.5530/pj.2019.11.157 
Petkova, N. Tr., Ognyanov, M. H., Vrancheva, R. Z., Zhelev, P. (2020). Phytochemical, nutritional and antioxidant characteristics of whitebeam (Sorbus aria) fruits. Acta Sci. Pol. Technol. Aliment., 19(2), 219-229. http://dx.doi.org/10.17306/J.AFS.2020.0786

Sikora, E., Bieniek, M. I., Borczak, B. (2013). Composition and antioxidant properties of fresh and frozen stored blackthorn fruits (Prunus spinosa L.). Acta Sci. Pol. Technol. Aliment., 12(4), 365-372.

Terzieva, A. V., Vrancheva, R. Z., Delchev, N. D. (2017). Antioxidant activity of different extracts of dried and frozen fruits of Schisandra chinensis (Turcz.) Baill. Bulg. Chem. Comm., 49(G), 78-82.

Termentzi, A., Kefalas, P., Kokkalou, E. (2006). Antioxidant activities of various extracts and fractions of Sorbus domestica fruits at different maturity stages. Food Chem., 98(4), 599-608. https://doi.org/10.1016/j.foodchem.2005.06.025

Welk, E., de Rigo, D., Caudullo, G. (2016). Sorbus aria in Europe: distribution, habitat, usage and threats. In $\mathrm{J}$.
San-Miguel-Ayanz, D. de Rigo, G. Caudullo, T. Houston Durrant, A. Mauri (Eds.), European atlas of forest tree species (pp. e01-e816). Luxembourg: Publ. Off. EU.

Zenkova, M., Pinchykova, J. (2019). Chemical composition of sea-buckthorn and highbush blueberry fruits grown in the Republic of Belarus. FSAB, 2(2), 121-129. https:// doi.org/10.30721/fsab2019.v2.i2.59

Zymone, K., Raudone, L., Raudonis, R., Marksa, M., Ivanauskas, L., Janulis, V. (2018). Phytochemical profiling of fruit powders of twenty Sorbus L. cultivars. Molecules, 23, 2593. https://doi.org/10.3390/molecules 23102593 